\title{
IDENTIFIKASI SURFAKTIN PADA PSEUDOMONAS FLUORESCENS ST1 PENGENDALI EFEKTIF PENYAKIT PUSTUL KEDELAI
}

\author{
Suskandini Ratih Dirmawati ${ }^{1}$
}

\begin{abstract}
Identification of surfactin in Pseudomonas fluorescens ST1 which effectively suppres soybean bacterial pustule. Identification of surfactin in Pseudomonas fluorescens ST1 filtrate was conducted in Plant Pest and Disease Laboratory, Bogor Agriculture University. The 48 hours cultured suspension of P. fluorescens ST1 with $10^{8} \mathrm{CFU} / \mathrm{ml}$ density was centrifuged to obtain the supernatant. The supernatant was analyzed for its surfactin content by High Performance Liquid Chromatography with Colum ODS-5 and eluen acetonitril and acetat acid. The result showed that surfactin was producted by $P$. fluorescens ST1 and this bioactive substance could suppres the bacterial pustule on soybean.
\end{abstract}

Key words : surfactin, Pseudomonas fluorescens

\section{PENDAHULUAN}

Kedelai (Glycine max L. Merr.) merupakan salah satu sumber protein nabati penting bagi penduduk Indonesia. Menurut Badan Pusat Statistik (2005), kebutuhan kedelai untuk konsumsi penduduk dan pakan ternak di Indonesia dari tahun ke tahun selalu menunjukkan peningkatan. Kebutuhan tersebut tidak dapat dipenuhi oleh produksi kedelai nasional karena berbagai kendala, salah satunya adalah penyakit pustul yang disebabkan oleh bakteri Xanthomonas axonopodis pv. glycines. Machmud (1990) menyatakan bahwa varietas kedelai unggul nasional maupun lokal di areal pertanaman kedelai di Lampung selalu terserang oleh bakteri penyebab pustul dan penurunan produksi akibat bakteri ini mencapai $50 \%$.

Sinclair \& Backman (1989) mengemukakan bahwa salah satu cara pengendalian penyakit pustul kedelai adalah menggunakan bakterisida. Menurut Goto (1992), efek bakterisida dimiliki oleh bakteri agensia hayati yang mungkin memproduksi antibiotik, lisozim, atau metabolit toksik seperti surfaktin sebagai mekanisme antagonisme terhadap bakteri lain. Menurut Ratih (2002), Pseudomonas fluorescens ST1 secara in vitro terbukti efektif menghambat pertumbuhan bakteri $X$. axonopodis pv. glycines N01, namun belum diketahui senyawa bioaktif yang terkandung pada bakteri agensia hayati tersebut. Menurut Lang dan Wagner (1993), beberapa jenis bakteri diantaranya $P$. fluorescens diindikasikan mampu menghasilkan senyawa antibiotik lipopeptida yang struktur kimianya mirip dengan surfaktin. Lebih lanjut dinyatakan bahwa surfaktin adalah lipopeptida siklik yang mempunyai efek lisis bagi sistem biologi mikroorganisme lain yang ada di sekitarnya. Surfaktin dapat menghambat pembentukan protoplasma bakteri lainnya.

Berdasarkan informasi tesebut maka perlu diidentifikasi adanya dugaan senyawa bioaktif berupa surfaktin yang terkandung dalam $P$. fluorescens ST1 yang terbukti efektif sebagai agensia hayati terhadap bakteri penyebab pustul kedelai.

\section{METODE PENELITIAN}

Penelitian dilaksanakan dari Januari sampai dengan Mei 2004 di Laboratorium Bakteriologi Tumbuhan Departemen Hama dan Penyakit Tumbuhan Fakultas Pertanian, Institut Pertanian Bogor. Isolat bakteri agensia hayati $P$. fluorescens ST1 maupun bakteri $X$. axonopodis pv. glycines N01 penyebab pustul kedelai diperoleh melalui isolasi dengan teknik pencawanan dari rizosfer kedelai di Natar, Lampung Selatan (Ratih, 2002). Selanjutnya isolat murni bakteri dipelihara dalam medium selektif King's B dengan komposisi proteose pepton, $\mathrm{K}_{2} \mathrm{HPO}_{4}, \mathrm{MgSO}_{4}$ dan gliserol untuk menunjukkan adanya pigmen fluoresein yang berpendar yang menjadi karakteristik $P$. fluorescens (Fahy \& Persley, 1983).

Isolat murni $P$. fluorescens $\mathrm{ST} 1$ berumur 48 jam dengan kerapatan $10^{8} \mathrm{CFU} / \mathrm{ml}$ dibuat $1,0 \mathrm{ml}$ suspensi, kemudian disentrifugasi menggunakan High Speed Micro Refrigerator Centrifuge MRX-151 Induction

\footnotetext{
${ }^{1}$ Jurusan Proteksi Tanaman, Fakultas Pertanian, Universitas Lampung J1. Prof. Soemantri Brodjonegoro No. 1 Bandar Lampung 35145
} 
Drive, kecepatan $11000 \mathrm{rpm}$ selama 30 menit. Supernatan yang diperoleh disaring dengan membran nitroselulosa berporositas 0,2 m agar diperoleh surfaktin yang tidak bercampur dengan sel bakteri.

Selanjutnya analisis surfaktin dilakukan dengan metode kromatografi cair bertekanan tinggi menggunakan kolom ODS-5 serta eluen asetonitril dan asam asetat (Lin, 1993). Sebagai senyawa standar digunakan surfaktin yang diproduksi oleh $B$. subtilis ATCC-21332 produk Sigma Laboratories.

\section{HASIL DAN PEMBAHASAN}

Analisis senyawa bioaktif dalam filtrat bakteri agensia hayati $P$. fluorescens ST1 menunjukkan adanya senyawa yang serupa dengan surfaktin. Struktur kimia surfaktin disajikan pada Gambar 1.

Surfaktin pada supernatan P. fluorescens ST1 dibandingkan dengan 100 ppm surfaktin standar yang berasal dari bakteri Bacillus subtilis ATCC-21332 (Sigma Laboratories). Gambar 2 dan 3 menunjukkan waktu retensi supernatan bakteri P.fluorescens ST1 adalah 4,38; 6,28; 7,66; 9,46 dan 10,53 menit dengan tiga puncak absorbansi dominan terdeteksi pada waktu retensi antara 6 sampai 11 menit. Dibandingkan dengan surfaktin standar yang diambil dari B. subtilis ATCC21332, kedua bakteri sama-sama menunjukkan 5 puncak absorbansi dengan waktu retensi 6,$04 ; 7,85 ; 10,77 ; 11,82$ dan 14,70 menit, tiga puncak absorbansi surfaktin standar dominan pada waktu retensi antara 7 hingga 11 menit.

Waktu retensi menjadi indikasi adanya senyawa surfaktin. Hal ini sesuai dengan penelitian Lin (1993) bahwa identifikasi surfaktin dengan metode kromatografi cair bertekanan tinggi menggunakan kolom ODS-5 serta eluen asetonitril dan asam asetat yang dilakukannya menghasilkan 5 puncak absorbansi dan 3 diantaranya dominan dengan waktu retensi antara 6 hingga 15 menit. Selanjutnya Desai dan Desai (1993) menjelaskan bahwa surfaktin yang terdeteksi pada puncak absorbansi dengan waktu retensi antara 6 hingga 15 menit merupakan senyawa yang tergolong lipopeptida siklik. Kemiripan absorbansi surfaktin P.fluorescens ST1 dengan $B$. subtilis ATCC-21332 merupakan indikasi bahwa surfaktin dalam supernatan P.fluorescens ST1 berupa lipopeptida yang serupa dengan surfaktin $B$. subtilis ATCC-21332. Menurut Desai \& Desai (1993), struktur serta sifat fisik kimia surfaktin yang diproduksi oleh $B$. subtilis ATCC-21332 sama dengan surfaktin yang diproduksi B. subtilis QMB atau likenisin yang

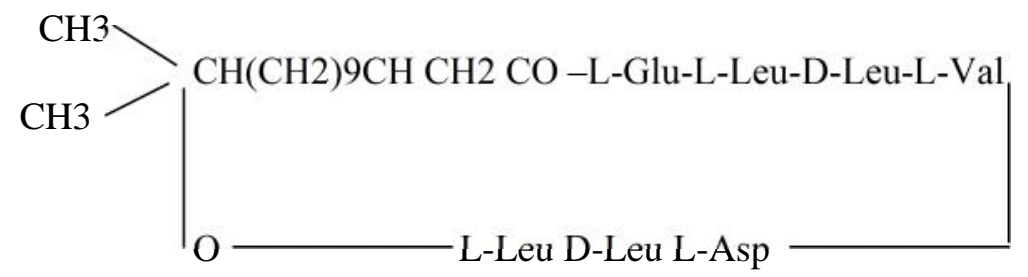

Gambar 1. Struktur kimia Surfaktin (Sumber: Hommel \& Ratledge, 1993)

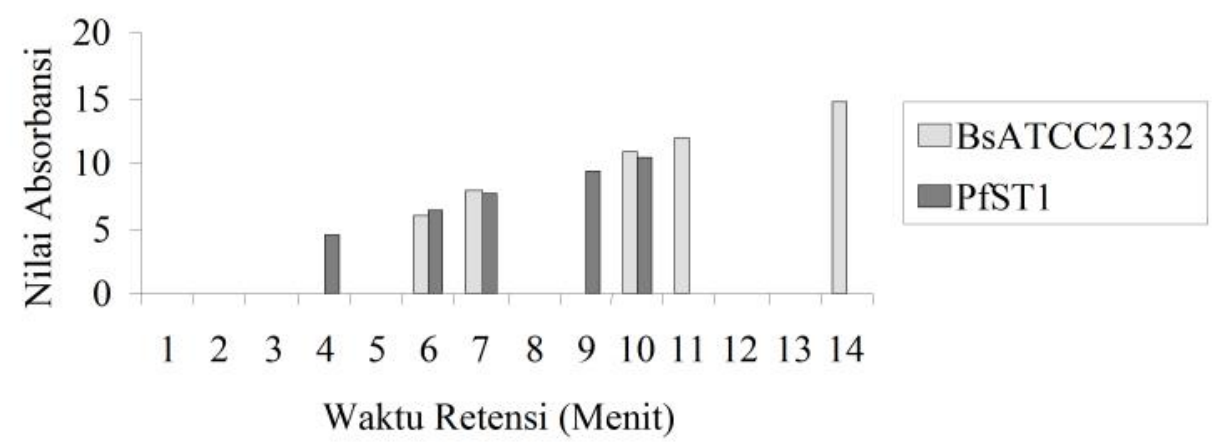

Gambar 2. Absorbansi dan Waktu Retensi yang ditunjukkan dalam Kromatografi Cair Tekanan Tinggi pada Surfaktin Standar dan bakteri PfST1 


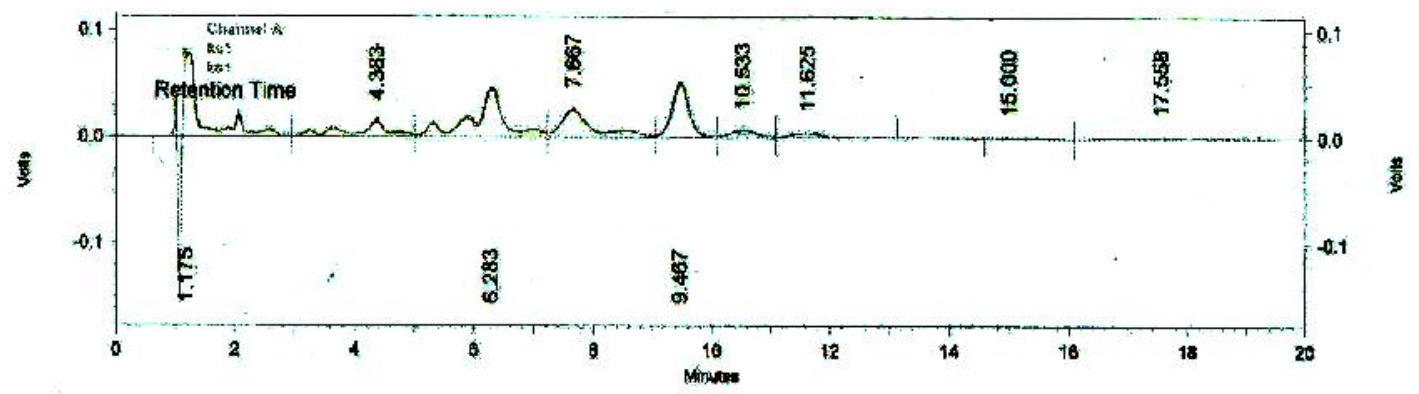

Gambar 3. Kromatogram supernatan P.fluorescens ST1

diproduksi oleh B. licheniformis $\mathrm{JF}_{2}$ atau BL 86. Dengan menggunakan metode kromatografi cair bertekanan tinggi, ketiga jenis senyawa yang tergolong biosurfaktan ini dapat terdeteksi dalam puncak absorbansi dengan waktu retensi yang berdekatan.

Lang \& Wagner (1993) menyatakan bahwa surfaktin yang merupakan lipopeptida siklik selain berfungsi menurunkan tegangan permukaan zat cair juga merusak sferoplas serta protoplas bakteri lain yang berada di dekat bakteri penghasilnya. Hal ini dinyatakan oleh Desai \& Desai (1993) bahwa surfaktin B.subtilis dengan konsentrasi $5 \mathrm{~g} / 1$ ternyata dapat menghambat pertumbuhan Mycobacterium spp. Fungsi surfaktin sebagai antimikroba berkaitan dengan kemampuannya mengikat molekul hidrofobik pada membran bakteri. Lebih lanjut dikemukakan oleh Hommel \& Ratledge (1993) bahwa keefektifan surfaktin sebagai senyawa antimikroba bergantung kepada konsentrasi surfaktin dan ketahanan membran mikroorganisme yang ada di sekitarnya yang dapat dihambatnya.

Berdasarkan informasi keefektifan $P$. fluorescens ST1 terhadap X. axonopodis pv. glycines N01 yang telah diteliti sebelumnya, tampaknya molekul hidrofobik pada membran bakteri penyebab pustul kedelai ini tidak terlalu kuat sehingga dapat diikat oleh senyawa surfaktin yang diproduksi oleh P. fluorescens ST1.

\section{SIMPULAN}

Agensia hayati $P$. fluorescens ST1 yang efektif menghambat $X$. axonopodis pv. glycines N01 ternyata mempunyai kandungan surfaktin serupa dengan surfaktin standar yang berasal dari B. subtilis ATCC-21332 dan tergolong senyawa lipopeptida.

\section{DAFTAR PUSTAKA}

Badan Pusat Statistik. 2005. Produksi Tanaman Padi dan Palawija di Indonesia. Survei Pertanian. Jakarta.

Desai, J.D. \& A.J. Desai. 1993. Production of Biosurfactants. Dalam Kosaric N, editor Biosurfactants. Production. Properties. Applications. Marcel Dekker Inc. New York. Hlm. 279-345.

Fahy , P.C. \& G.J. Persley. 1983. Plant Bacterial Diseases. A Diagnostic Guide. Academic Press. Australia. 
Goto, M. 1992. Fundamentals of Bacterial Plant Pathology. Academic Press Limited London.

Hommel, R.K. \& C. Ratledge. 1993. Biosynthetic Mechanism of Low Molecular Weight Surfactants and Their Precursor Molecules. Dalam Kosaric N, editor Biosurfactans. Production. Properties. Applications. Marcel Dekker Inc. New York. Hlm. 206-278.

Lang, S. \& F. Wagner . 1993. Bioconversion of Oils and Sugars to Glycolipids. Dalam Kosaric N, editor. Biosurfactans. Production. Properties. Application. Marcel Dekker. New York. Hlm 346-382.

Lelliot, R.A. \& D.E. Stead. 1987. Methods for the Diagnosis of Bacterial Diseases of Plants. Blackwell Scientific Publication. Australia.
Lin, S. 1993. Biosurfactant : Recent Advances. J. Chem. Tech. Biotechnol. 66 : 109-120.

Machmud, M. 1990. Penyakit Bakteri pada Tanaman Pangan dan Hortikultura: Masalah dan Strategi Pengendaliannya. Dalam Pawiroesoemardjo S et al.editor. 1990. Perlindungan Tanaman. Menunjang Terwujudnya Pertanian Tangguh dan Kelestarian Lingkungan. Penerbit PT. Agricon. Bogor. Hlm. 233-251.

Dirmawati, R. S. 2002. Kajian Pengendalian Ramah Lingkungan Terhadap Penyakit Pustul Bakteri (Xanthomonas axonopodis pv, glycines) pada Kedelai secara In Vitro. Makalah Ilmiah. Program Pascasarjana Institut Pertanian Bogor. Tidak dipublikasikan.

Sinclair, J.B. \& B.A. Backman. 1989. Compendium of Soybean Diseases. 3 rd Ed. The American Phytopathological Society. United States of America. 